DOI 10. $18307 / 2021.0310$

(C) 2021 by Journal of Lake Sciences

\title{
黄河流域多时空尺度土地利用与水质的关系
}

\author{
郭羽羽 ${ }^{1}$, 李思悦 ${ }^{2}$, 刘 冨 $^{1}$, 张 静 ${ }^{* * *}$ \\ (1: 重庆师范大学地理与旅游学院, 重庆 401331) \\ (2: 中国科学院重庆绿色智能技术研究院生态水文研究中心, 重庆 400714)
}

\begin{abstract}
摘 要: 为探究不同时空尺度土地利用与水质的相互关系, 以黄河流域为研究对象,基于 2018 年河流水质与土地利用数 据, 提取 3 种空间尺度 (1000 m 河段缓冲区、 $500 \mathrm{~m}$ 河岸带缓冲区、子流域) 的景观格局指数,结合 4 个季节河流水质指标， 采用圥余分析方法定量探讨土地利用对河流水质的多时空尺度影响, 获得水质资源管理最有效的时空尺度. 结果表明: (1) 在 3 种空间尺度下, 耕地和草地占比最大. 斑块密度 $(P D)$ 在 $1000 \mathrm{~m}$ 河段缓冲区尺度下更大, 香农多样性指数 (SHDI) 在 3 种空间尺度下变化不大; (2) 水质指标季节性和空间性存在显著差异, 夏季水质优于冬季; (3) 土地利用在夏季和 $1000 \mathrm{~m}$ 河段缓冲区尺度下对水质影响最显著; (4) 不同景观格局指数对河流水质产生的影响不同, 耕地面积占比和林地 面积占比、未利用地面积占比和 $S H D I$ 对水质影响最为显著, 除了耕地面积占比和 $P D$ 值的增加会导致水质下降外, 其余 土地利用指数在大多数时空尺度下均可改善水质. 该研究基于不同的时空尺度对土地利用与水质的关系进行定量研究, 为合理规划土地资源提供参考,从而保护流域水质安全.
\end{abstract}

关键词: 土地利用;多尺度效应;圥余分析;水质;黄河流域

\section{Relationship between landscape pattern and water quality of the multi-scale effects in the Yellow River Basin*}

\author{
Guo Yuyu ${ }^{1}$, Li Siyue ${ }^{2}$, Liu Rui ${ }^{1} \&$ Zhang Jing ${ }^{1 * *}$ \\ (1: School of Geography and Tourism, Chongqing Normal University, Chongqing 401331, P.R.China) \\ (2: Research Center for Eco-hydrology, Chongqing Institute of Green and Intelligent Technology, Chinese Academy of Sci- \\ ences, Chongqing 400714, P.R.China)
}

\begin{abstract}
To explore the relationship between landscape patterns and water quality at different spatial and temporal scales, we choose the Yellow River Basin as the research object. Based on the data of river water quality and land use in 2018, the three spatial scales ( $1000 \mathrm{~m}$ reach buffer, $500 \mathrm{~m}$ riparian corridor buffer, and catchment) of the landscape pattern were extract, combined with four seasons of water quality, using redundancy analysis to quantitatively explore the impact of landscape pattern on water quality at multiple spatial and temporal scales, to obtain the most effective scales for water quality management. The results showed that: (1) Under the three spatial scales, the proportion of farmland and grassland was the largest. The value of patch density $(P D)$ was larger in reach scale, while the Shannon diversity index (SHDI) varied little at the three scales, and the spatial distribution was relatively balanced. (2) There were significant differences in seasons and spatial scales of water quality indicators, and water quality in the summer was better than that in the winter. (3) The landscape pattern had the most significant impact on water quality in the summer and the reach scale. (4) Different landscapes had different impact on water quality. That is, farmland, forest, unused land and $P D$ were the most significant influence on water quality. Except for the increase in farmland and $P D$ value, which will lead to a decline in water quality, other land use indices can improve water quality at most temporal and spatial scales. The relationship between landscape pattern and water quality was quantitatively studied based on different scales, which provides references for optimizing landscape pattern and rational planning of land use, to protect water quality safety in the river basin.
\end{abstract}

* 2020-07-01 收稿;2020-09-16 收修改稿.

国家自然科学基金项目 (41801063)、重庆市教委科学技术研究计划项目 (KJQN201900548)、重庆市自然科学基金 项目 ( cstc2020jcyj-msxmX0549) 和重庆师范大学基金项目(20XLB022)联合资助.

** 通信作者;E-mail:zhangjing@ cqnu.edu.cn. 
Keywords: Landscape pattern; multi-scale effects; redundancy analysis; water quality; Yellow River Basin

水资源是人类生存和发展所依赖的重要资源, 随着社会的不断进步, 水资源分配不均的问题日渐凸 显 $^{[1]}$. 水质是水资源质量的决定因素, 点源污染目前已基本得到控制, 非点源污染成为影响水质的关键 ${ }^{[2]}$. 土地利用变化对生态过程、地表径流、水文循环产生一系列深刻的影响,进而影响河流水质安全 ${ }^{[3]}$. 因此,探 讨土地利用与水质之间的关系, 对土地利用的管理规划及水生态环境资源的有效保护具有重要意义.

近年来, 土地利用对水质指标的影响机制研究已成为国内外学者研究的热点 ${ }^{[4-8]}$. 目前, 大部分的研究 是针对河段 ${ }^{[9-11]}$ 、河岸带 ${ }^{[12-13]}$ 、子流域 ${ }^{[14-16]}$ 等空间尺度, 研究方法主要包括相关分析 ${ }^{[17]}$ 、圥余分析 ${ }^{[11,13]}$ 、 SWAT 模型 ${ }^{[18]}$ 、地理加权回归模型 ${ }^{[19]}$ 、多元线性回归 ${ }^{[20]}$ 等. 例如, 杨洁等 ${ }^{[9]}$ 认为在 $1000 \mathrm{~m}$ 大范围尺度, 土地 利用对水质的影响更加显著, 城镇用地、旱地及水田影响显著, 景观聚集程度与水质指标呈正相关, 与破碎 度呈负相关; Shi 等 ${ }^{[10]}$ 研究表明在 $1000 \mathrm{~m}$ 缓冲区尺度下, 土地利用与河流水质的相关性最高, 且不同的土地 利用指标对水质有不同的尺度效应; 张殷俊等 ${ }^{[12]}$ 研究了巢湖流域缓冲区尺度下土地利用与水质之间的关系 及影响因素, 结果表明土地利用类型对水环境影响具有尺度效应, 林地对水质具有正面影响, 建设用地具有 负面影响, 耕地对水质的影响具有复杂性; 汪昱昆等 ${ }^{[13]}$ 报道了上海市河网水质对河岸带土地利用的响应,结 果发现土地利用在 $500 \mathrm{~m}$ 和 $1000 \mathrm{~m}$ 缓冲区尺度对水质解释最强, 建设用地与大多数水质指标呈正相关; 康 文华等 ${ }^{[21]}$ 发现赤水河流域景观组成在河岸带尺度对水质解释率最高, 建设用地和耕地具有负面影响, 林地 则为正面影响; de Mello 等 ${ }^{[15]}$ 研究发现萨拉普伊河 (Sarapuí River) 流域的土地利用/土地覆盖在子流域尺度 比河岸带尺度更好地解释了整体水质的变化, 森林覆盖在保持水质清洁方面发挥着重要作用,而农业和城 市地区则导致水质恶化; Zhang 等 ${ }^{[16]}$ 发现三峡库区的土地利用在子流域尺度比河岸带尺度对所有水质影响 更显著; Ding 等 ${ }^{[20]}$ 认为在东江流域子流域尺度相比于河岸带或点缓冲尺度更能解释总体水质变化. 综上, 土地利用对水质存在显著影响, 但其对水质指标解释能力最强的空间尺度存在不确定性, 部分研究结果表 明土地利用在缓冲区尺度下对水质解释能力更显著, 而另一部分表明土地利用在子流域尺度下对水质的影 响更强. 同时, 土地利用特征的差异、水文过程的不同都会导致景观与水质的相关性及相关程度存在差 异 ${ }^{[22]}$. 因此, 尺度效应成为研究重点, 且多体现为子流域尺度和不同距离的缓冲区尺度之间的差异 ${ }^{[14,22]}$, 研 究不同空间尺度土地利用与水质的定量关系, 不仅有利于优化土地利用结构, 还可以控制面源污染, 有效进 行水质管理.

黄河是我国的母亲河, 也是我国水土保持、资源保护的重点流域 ${ }^{[23]}$. 由于土壤、地形、降水等自然因素 的影响, 黄河泥沙淤积严重, 加上人类活动不断加剧对河流生态的破坏, 河流水质问题日渐凸显 ${ }^{[24]}$. 以往研 究多针对中小流域探讨土地利用与水质之间的关系 ${ }^{[25-26]}$, 而黄河流域跨度大, 不同河段土地利用差异明显; 同时, 黄河流域由于其特殊的气候特征, 年际径流变化明显, 导致水质指标在不同季节具有显著差异. 但目 前少有针对黄河流域进行土地利用与水质关系分析的研究, 刘绿怡等 ${ }^{[27]}$ 以伊河流域为研究区, 基于不同距 离的点缓冲区分析景观空间异质性对水质的影响. 虽然伊河流域位于黄河中下游的中心位置, 但其研究只 探讨了河段缓冲区尺度,未考虑到河岸带、子流域等多种尺度土地利用对水质影响的差异性. 吕振豫等 ${ }^{[28]}$ 以 2004-2015 年黄河流域上、中、下游 9 个监测断面和 4 个水质指标的监测数据为研究对象, 分析了黄河流 域的水质达标情况及各水质指标的时空演变特征, 虽然其研究对象与本研究一致, 但他们只研究了水质达 标情况及各水质指标的时空演变特征, 并未定量探讨形成其研究结果的原因. 因此, 本研究选取黄河流域作 为研究区域, 综合运用 GIS 技术、单因素方差分析 (analysis of variance, ANOVA) 和圥余分析 (redundancy analysis, RDA) 等方法, 定量探讨流域不同时空尺度下土地利用指数与水质的关系, 旨在找出对黄河流域水 质影响最显著的时空尺度及土地利用, 为优化土地利用、加强水质保护提供科学参考.

\section{1 材料与方法}

\section{1 研究区概况}

黄河是中国第二大河, 地处 $31.48^{\circ} \sim 41.56^{\circ} \mathrm{N}, 95.04^{\circ} \sim 117.99^{\circ} \mathrm{E}$ 之间, 流域面积达 $7.95 \times 10^{5} \mathrm{~km}^{2}$, 是我国 生态保护、流域治理的重点对象 (图 1). 黄河流域幅员辽阔, 地貌类型多样, 由东至西海拔逐渐升高, 横跨黄 
淮海平原、黄土高原、内蒙古高原及青藏高原 4 个地貌单元. 流域内草地、林地及耕地景观广泛分布,植被疏 松, 部分地区土壤盐碱化现象严重 ${ }^{[29]}$. 黄河流域大部分地区位于干旱、半干旱地区,各地区之间气候差异显 著, 年平均气温在 $7^{\circ} \mathrm{C}$ 左右, 光照充足, 湿度小, 蒸发大, 日夜温差明显; 流域内降水量偏少, 全流域多年平均 降水量为 $451 \mathrm{~mm}^{[30]}$. 在气候和地貌的双重影响下, 黄河流域水资源稀缺, 年径流量仅占全国 $2 \%$, 且年内、年 际变化大, 流量呈持续减小趋势, 枯水期长, 水土流失严重 ${ }^{[31]}$. 近年来, 随着黄河流域经济的飞速发展, 加速 了人口城市化的进程和乡镇工业的发展, 从而导致工矿企业和城镇居民生活的废污水急剧增加, 且流域内 耕地化肥、农药等的过量使用, 致使黄河流域水质遭到严重污染. 据前人调查研究显示, 1994 年黄河流域干 流污染物超标河长占总河长的 $57.4 \%, 2003$ 年超标河长增至 $78.1 \%$, 主要超标项目包括溶解氧 ( DO) 、氨氮 $\left(\mathrm{NH}_{3}-\mathrm{N}\right)$ 和高锰酸盐指数 $\left(\mathrm{COD}_{\mathrm{Mn}}\right)$ 等 ${ }^{[28]}$. 从 2004-2015 年, 黄河流域的水质达标率由 $48.5 \%$ 增加至 $77.4 \%$, 整体上呈逐步改善的趋势, 但黄河中游地区水质污染严重, 如山西运城河津大桥监测站点和陕西渭南潼关 吊桥监测站点水质达标率仅分别为 $0.2 \%$ 和 $4.2 \%{ }^{[28]}$.

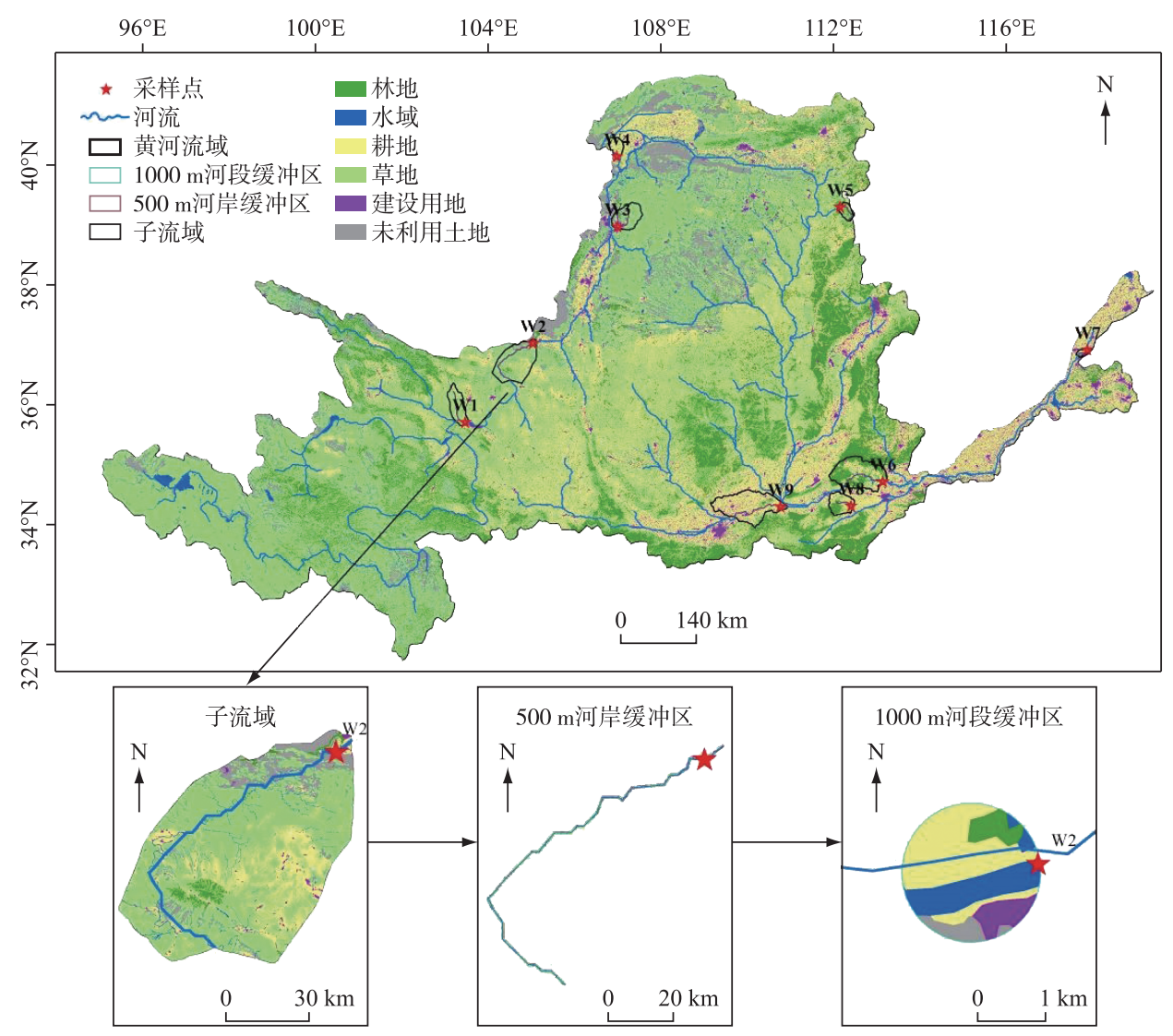

图 1 黄河流域水质监测站的空间分布及子流域、河岸带、河段 3 个空间尺度 (W1～W9 代表 黄河流域内 9 个监测站点, 依次为 W1-甘肃兰州新城桥监测站点, W2-宁夏中卫新墩监测站点,

W3-内蒙古乌海海勃湾监测站点, W4-内蒙古包头画匠营子监测站点, W5-山西忻州万家寨 监测站点, W6-河南济源小浪底监测站点, W7-山东济南讶口监测站点, W8-山西运城河津大桥监测站点, W9-陕西渭南潼关吊桥监测站点)

Fig.1 Spatial distribution of water quality monitoring stations in the Yellow River Basin and the three spatial scales (catchment, riparian corridor and reach) 


\section{2 数据获取}

黄河流域水质数据由国家地表水水质自动监测实时数据发布系统 ( http ://123.127.175.45: 8082/) 获 取, 结合前人研究 ${ }^{[28]}$, 选取黄河上游甘肃兰州新城桥、宁夏中卫新墩、内蒙古乌海海勃湾、内蒙古包头画匠营 子, 中游山西忻州万家寨、山西运城河津大桥、陕西渭南潼关吊桥、河南济源小浪底和下游山东济南胨口共 9 个重要的具有代表性的监测站点, 大部分监测点位于黄河干流附近. 于 2018 年 2 月 7 日-2019 年 2 月 7 日 每天中午 $12: 00$ 收集为期一年的水质数据, 将此数据作为一年内每天的日均值, 并分别对不同监测站点不 同季节的监测数据求平均值. 前人研究结果显示, 黄河流域的水体污染物未达标项目主要为 $\mathrm{DO} 、 \mathrm{NH}_{3}-\mathrm{N}$ 、 $\mathrm{COD}_{\mathrm{Mn}}$ 等指标 ${ }^{[28]}$, 故本研究的水质参数选取 $\mathrm{pH} 、 \mathrm{DO} 、 \mathrm{NH}_{3}-\mathrm{N}$ 和 $\mathrm{COD}_{\mathrm{Mn}} 4$ 个指标.

DEM 数据由中国科学院资源环境科学数据中心获取 (http://www.resdc.cn), 高程数据分辨率为 $30 \mathrm{~m}$, 可用于提取水系. 为了与水质数据时间对应, 由地理空间数据云平台获取 2018 年研究区域对应的 Landsat 8 OLI 遥感影像数据, 空间分辨率为 $30 \mathrm{~m}$. 采取支持向量机法与人工目视解译相结合的方法, 参考《土地利用 现状分类》标准, 得到林地、草地、耕地、建设用地、水域及未利用土地共 6 类土地利用类型. 经混淆矩阵精度 验证, 分类总精度为 $86.36 \%$, Kappa 系数达到 0.81 , 符合精度要求.

\section{3 不同空间尺度土地利用指数的计算}

参考国内外相关研究, 河段、河岸带及子流域 3 个空间尺度下土地利用对水质具有较好的预测效 果 ${ }^{[10,20,22]}$. 再结合黄河流域区域特征, 黄河干流宽度多为 $300 \sim 500 \mathrm{~m}$, 且小范围内土地利用变化程度较小, 故将土地利用指标分为子流域、500 $\mathrm{m}$ 河岸带缓冲区和 $1000 \mathrm{~m}$ 河段缓冲区 3 个空间尺度. 基于 ArcGIS 10.4 平台, 结合 DEM 高程数据和中国科学院资源环境科学数据中心 (http://www.resdc.cn/) 发布的二级流域数 据, 并参考 Shi 等 ${ }^{[10]}$ 划分子流域的方法, 对黄河流域水系进行提取, 并以监测点为出水口提取对应的子流域. $1000 \mathrm{~m}$ 河段缓冲区以监测点上游 $1000 \mathrm{~m}$ 处为圆心, 设置半径为 $1000 \mathrm{~m}$ 的点缓冲区; $500 \mathrm{~m}$ 河岸带缓冲区沿 监测点上溯, 以子流域为边界截取河流向左右两岸延伸 $500 \mathrm{~m}$ 生成对应的线缓冲区. 通过对缓冲区范围和 土地利用数据作相交处理,得到各空间尺度的土地利用数据,为景观指数的计算提供数据基础.

基于前人研究结果, 土地利用类型百分比 (PLAND) 指数、斑块密度 $(P D)$ 和香农多样性指数 (SHDI) 对 水质影响较显著, 且由于研究区内景观类型的差异, $P D$ 和 $S H D I$ 对水质的作用结果存在不确定性 ${ }^{[6]}$. 因此, 本研究在景观类型水平上选用 PLAND 指数, 用于计算各土地斑块占景观总面积的比例; 在空间格局上选取 了 $P D$ 和 $S H D I$ 指数. $P D$ 反映了景观密集程度的差异, $S H D I$ 为邻近度指标, 可表征景观异质性, 土地利用类 型越丰富, SHDI 值越高 ${ }^{[6]}$. 以上景观格局指数由 Fragstats v4.2.1 软件计算得到, 综合体现了不同空间尺度下 的个体要素和整体景观特征.

\section{4 数据统计与处理}

利用 SPSS Statistics 19 软件, 首先对水质数据进行 K-S 检验, 符合正态分布, 对其进行 ANOVA 单因素方 差分析, 用于比较水质指标之间的时空差异性. 同时, 对土地利用指数进行单因素方差分析, 得到各指数的 空间差异性.

圥余分析 (redundancy analysis, RDA) 作为常见的线性直接梯度排序分析方法, 能够反映多个环境变量 对所有物种变量的影响, 同时可以得到单个环境因子对物种变化的方差贡献率 ${ }^{[13]}$. 运用 Canoco 5.0 软件, 首 先对物种变量进行趋势对应分析 (detrended correspondence analysis, DCA), 若分析结果得到梯度长度 (gradients length) 第 1 轴小于 3.0 , 则选择 RDA, 若大于 4.0 , 则选择典范对应分析 (canonical correspondence analysis, CCA), 若值介于 3.0 4.0 之间, 则两种分析方法均可使用 ${ }^{[11]}$. 本研究中土地利用指数为环境变量, 水质 数据为物种变量, 得到 DCA 结果均小于 3.0, 因此, 选用 RDA 方法定量探讨黄河流域所有土地利用指数对全 部水质指标的多时空尺度影响, 并通过单个土地利用指数对水质变化的方差贡献率大小得到对水质影响显 著的土地利用格局.

\section{2 结果与分析}

\section{1 土地利用特征}

以黄河流域 9 个监测站点为中心, 提取对应的河流及子流域, 得到 $1000 \mathrm{~m}$ 河段缓冲区、 $500 \mathrm{~m}$ 河岸带缓 
冲区和子流域 3 个空间尺度对应的土地利用类型(图 1), 土地利用类型比例和景观格局指数变化如图 2 , 表 1 所示. 研究区内景观分布整体以耕地和草地为主, 不同空间尺度下, 景观组成和空间格局存在差异. 其中, $P D 、 S H D I$ 、林地和水域景观空间差异性显著 $(P<0.05$ ) (图 2, 表 1). $1000 \mathrm{~m}$ 河段缓冲区尺度下, 景观类型面 积占比表现为耕地 $>$ 草地 $>$ 水域 $>$ 未利用土地 $>$ 建设用地 $>$ 林地 (图 2). $500 \mathrm{~m}$ 河岸带缓冲尺度景观类型 面积占比表现为耕地 $>$ 草地 $>$ 水域 $>$ 未利用土地 $>$ 林地 $>$ 建设用地, 建设满用地面积占比大幅下降, 而草 地、林地面积占比上升 (图 2). 子流域尺度下, 耕地和草地仍为主要景观, 林地次之, 建设用地、未利用土地 和水域面积占比均较小 (图 2). 在多数空间尺度下, $P D$ 的值表现为 $1000 \mathrm{~m}$ 河段缓冲区 $>500 \mathrm{~m}$ 河岸带缓冲 区 > 子流域, 河段尺度景观斑块更加破碎, 子流域尺度下曲线变化趋势相对平缓(表 1). SHDI 指数表现为 $500 \mathrm{~m}$ 河岸带缓冲区 > 子流域 > $1000 \mathrm{~m}$ 河段缓冲区, 其中, 河岸带和子流域尺度下 SHDI 均值较为接近, 土 地利用类型相对丰富,空间分布相对均衡 (表 1 ).

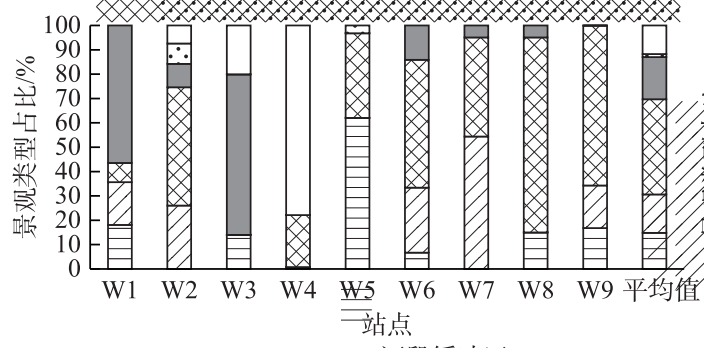

(a) $1000 \mathrm{~m}$ 河段缓冲区

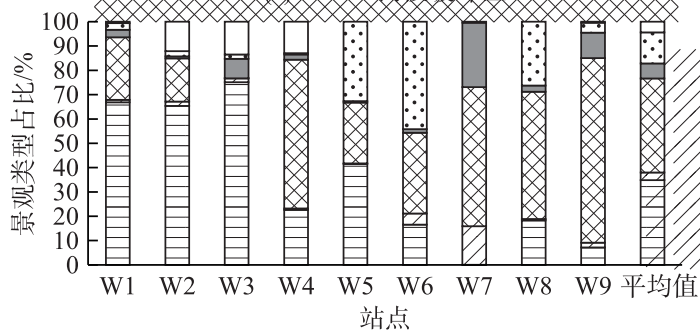

(c) 子流域

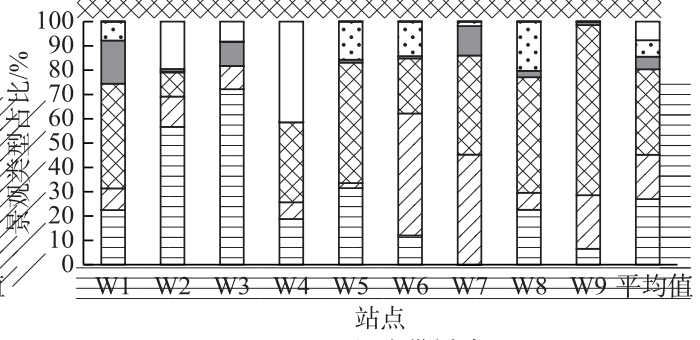

(b) 500 m河岸带缓冲区

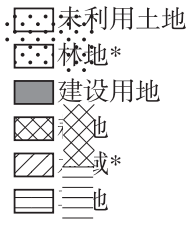

图 2 黄河流域各空间尺度景观类型组成(平均值为在不同空间尺度下各土地利用类型总面积所占比例; 图例后 $*$ 表示景观类型占比的空间性差异显著, * 表示 $P<0.05, * *$ 表示 $P<0.01$ )

Fig.2 Statistics of landscape proportions in different spatial scales in the Yellow River Basin

表 1 黄河流域各空间尺度景观格局指数*

Tab.1 Landscape metrics in different spatial scales in the Yellow River Basin

\begin{tabular}{|c|c|c|c|c|c|c|c|c|c|c|c|}
\hline 空间尺度 & 指数 & W1 & W2 & W3 & W4 & W5 & W6 & W7 & W8 & W9 & 均值 \\
\hline \multirow[t]{2}{*}{$1000 \mathrm{~m}$ 河段缓冲区 } & $P D /\left(\right.$ 个 $\left./ \mathrm{hm}^{2}\right)$ & 1.91 & 3.18 & 3.18 & 0.96 & 4.14 & 2.55 & 1.27 & 3.82 & 1.59 & $2.51^{\mathrm{a}}$ \\
\hline & SHDI & 1.14 & 1.33 & 0.87 & 0.56 & 0.77 & 1.15 & 0.84 & 0.61 & 0.88 & $0.91^{\mathrm{b}}$ \\
\hline \multirow[t]{2}{*}{$500 \mathrm{~m}$ 河岸带缓冲区 } & $P D /\left(\right.$ 个 $\left./ \mathrm{hm}^{2}\right)$ & 2.85 & 1.24 & 0.93 & 1.92 & 3.27 & 2.13 & 1.63 & 2.57 & 0.90 & $1.94^{\mathrm{b}}$ \\
\hline & SHDI & 1.42 & 1.20 & 0.90 & 1.23 & 1.14 & 1.26 & 1.05 & 1.29 & 0.83 & $1.15^{\mathrm{a}}$ \\
\hline \multirow[t]{2}{*}{ 子流域 } & $P D /\left(\right.$ 个 $\left./ \mathrm{hm}^{2}\right)$ & 0.66 & 0.26 & 0.14 & 0.64 & 1.12 & 0.48 & 0.57 & 0.60 & 0.56 & $0.56^{\mathrm{c}}$ \\
\hline & SHDI & 0.90 & 1.03 & 0.83 & 1.04 & 1.12 & 1.23 & 0.99 & 1.13 & 0.86 & $1.01^{\mathrm{a}}$ \\
\hline
\end{tabular}

* 表中 $P D$ 和 $S H D I$ 为景观格局指数, 其中, $P D$ 为斑块密度, $S H D I$ 为香农多样性指数;2) $P D$ 和 $S H D I$ 的统计值为各站点均 值,不同的小写字母上标表示景观格局空间差异显著 $(P<0.05)$.

\section{2 水质数据时空变化特征}

流域水质参数的季节差异和空间性如图 3 所示. 黄河流域水质参数在时空尺度上均表现出明显的差异 性. 从季节变化来看, 除了 $\mathrm{COD}_{\mathrm{Mn}}$, 其余的水质指标均呈现出明显的季节变化 $(P<0.05)$ (图 3 ). 其中参数 
$\mathrm{pH}$ 和 $\mathrm{NH}_{3}-\mathrm{N}$ 的变化趋势类似, 整体表现为冬季 $>$ 春季 $>$ 秋季 $>$ 夏季, 且 $\mathrm{pH}$ 标准差在 4 个季节均相对最 小, 监测点数据相对稳定 (图 3). DO 浓度变化规律为冬季 $>$ 秋季 $>$ 春季 $>$ 夏季, $\mathrm{COD}_{\mathrm{Mn}}$ 在各季节变化不大, 表现为春、夏季略高于秋、冬季 (图 3). 从各监测点统计值的空间变化来看, 4 个水质参数均呈现出明显的空 间变化 $(P<0.05)$ （图 3). 冬季水质指标 $\mathrm{DO}$ 浓度的空间差异最显著 $(P<0.05)$, 其次是 $\mathrm{pH}$ 在夏季空间差异显 著 $(P<0.05)$ (图 3). 在多数季节尺度下, $\mathrm{NH}_{3}-\mathrm{N}$ 和 $\mathrm{COD}_{\mathrm{Mn}}$ 浓度的变化规律表现为 $\mathrm{W} 8$ ( 山西运城河津大桥监 测站点) 最大, $\mathbb{W} 4$ (内蒙古包头画匠营子监测站点) 和 W6 (河南济源小浪底监测站点) 较小 (图 3).

$\square$ 春季 $\square$ 夏季 $\sqsubseteq$ 秋季 欧 冬季
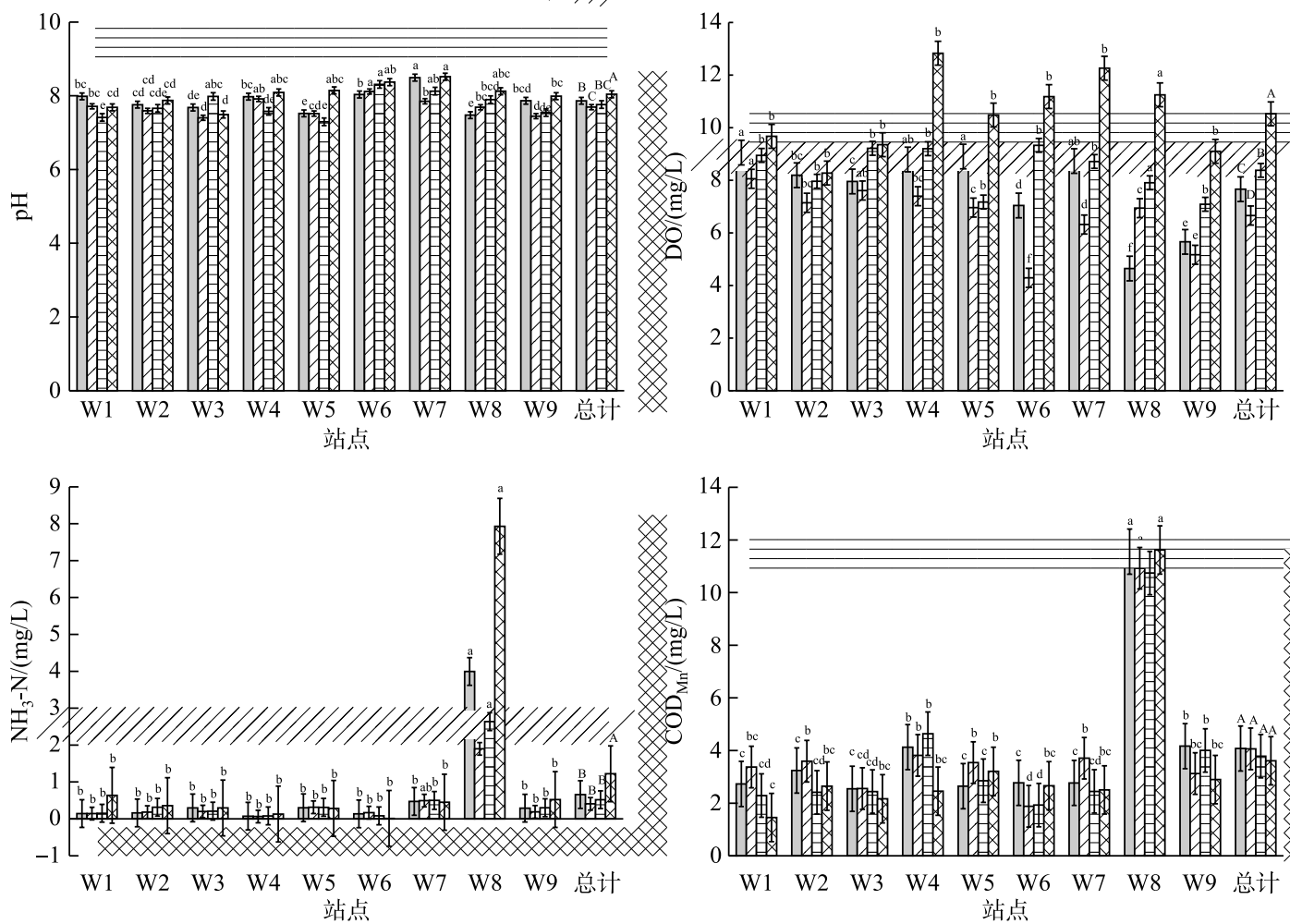

图 3 不同季节黄河流域水质参数的描述性统计 (水质参数包括 $\mathrm{pH}$ 、溶解氧 ( DO)、 氨氮 $\left(\mathrm{NH}_{3}-\mathrm{N}\right)$ 和高锰酸盐指数 $\left(\mathrm{COD}_{\mathrm{Mn}}\right)$; 不同字母表示水质的差异显著 $(P<0.05)$, 小写字母表示空间差异显著,大写字母表示季节差异显著)

Fig.3 Descriptive statistics of water quality parameters in the Yellow River Basin in different seasons

\section{3 不同时空尺度土地利用对水质的影响关系}

不同时空尺度下土地利用与水质的 RDA 结果如表 2 和图 4 所示, 结果表明, 土地利用在夏季和 $1000 \mathrm{~m}$ 河段缓冲区对水质变量的解释率最大, 且前两轴对水质指标解释率较高, 第 1 轴解释率至少达到 $61.39 \%$,为 第 2 轴解释率的 5 倍之多, 说明土地利用对水质的影响关系主要取决于第 1 轴的解释率 (表 2). 对于空间尺 度, 在春季和冬季, 土地利用对水质的空间尺度影响强度均表现为 $1000 \mathrm{~m}$ 河段缓冲区 $>500 \mathrm{~m}$ 河岸带缓冲 区 > 子流域尺度, 夏季和秋季则表现为 $1000 \mathrm{~m}$ 河段缓冲区 > 子流域 > $500 \mathrm{~m}$ 河岸带缓冲区尺度, 但 4 个季 节下土地利用对水质的空间尺度影响均在 $1000 \mathrm{~m}$ 河段缓冲区尺度下最强 (表 2). 对于时间尺度, 3 种空间 尺度下土地利用对水质影响最显著的时间尺度均为夏季 (表 2). 在不同的时空尺度下, 对水质影响最剧烈 的土地利用指数有所不同, 对于 $1000 \mathrm{~m}$ 河段缓冲区尺度, 对水质影响最大的解释变量为耕地面积占比 (30.6\% 45.1\%) 和 SHDI (23.0\% 25.4\%), 在 $500 \mathrm{~m}$ 河岸带缓冲区尺度下解释变量主要是林地面积占比 
( 27.4\% 44.1\%) 和耕地面积占比 ( 10.1\% 19.4\%), 耕地面积占比 ( $11.4 \% \sim 11.5 \%)$ 和未利用地面积占比 ( $10.0 \% \sim 10.9 \%$ ) 在子流域尺度下对水质影响较大 (表 2). 综上, 对于各个时空尺度, 对水质影响最显著的土 地利用指数为耕地面积占比、林地面积占比、未利用地面积占比和 SHDI.

黄河流域景观指数与水质参数的 RDA 排序图如图 4 所示, RDA 排序图中箭头之间的夹角表示变量之 间的相关性, 夹角等于零时, 表示两者不相关, 夹角小于 $90^{\circ}$ 时, 表示两者为正相关, 夹角大于 $90^{\circ}$ 则为负相 关. 箭头夹角的余弦值越大, 两者之间相关性越强; 且箭头的长短也可以表示相关性的强弱, 箭头越长, 相关 性越强, 反之相关性越弱 ${ }^{[11]}$. 不同土地利用指数与水质相关性存在差异, 在多数时空尺度下, 多数土地利用 指数与水质指标 $\left(\mathrm{NH}_{3}-\mathrm{N}\right.$ 和 $\left.\mathrm{COD}_{\mathrm{Mn}}\right)$ 呈负相关, 如草地面积占比、水域面积占比、未利用土地面积占比和 $S H D I$ 等指数; 耕地面积占比和 $P D$ 指数与水质指标呈正相关, 分别在 $500 \mathrm{~m}$ 河岸带缓冲区尺度和 $1000 \mathrm{~m}$ 河 段缓冲区尺度表现出较强的相关性 (图 4). 在多数时空尺度下, 耕地面积占比、林地面积占比、未利用地面 积占比与水质指标相关性最强 (图 4).

表 2 黄河流域土地利用变量解释总体营养物质变化比例的 RDA 结果 *

Tab.2 The redundancy analysis (RDA) results for the percentage of the overall nutrient change explained by the land use variables in the Yellow River Basin

\begin{tabular}{|c|c|c|c|c|c|c|c|}
\hline \multirow{2}{*}{ 季节 } & \multirow{2}{*}{ 空间尺度 } & \multicolumn{3}{|c|}{ 解释率/\% } & \multirow{2}{*}{ Pseudo- $F$} & \multirow{2}{*}{$P$ 值 } & \multirow{2}{*}{ 解释变量 (贡献率/\% ) } \\
\hline & & 第 1 轴 & 第 2 轴 & 所有轴 & & & \\
\hline \multirow[t]{3}{*}{ 春季 } & $1000 \mathrm{~m}$ 河段缓冲区 & 79.21 & 13.07 & 94.63 & 4.9 & 0.004 & Farmland (45.1) 、SHDI(23.0) \\
\hline & $500 \mathrm{~m}$ 河岸带缓冲区 & 64.08 & 13.37 & 79.65 & 3.0 & 0.094 & Forest (32.9)、Farmland (10.1) \\
\hline & 子流域 & 63.01 & 11.60 & 76.77 & 0.9 & 0.372 & Farmland(11.4)、Grass (9.8) \\
\hline \multirow[t]{3}{*}{ 夏季 } & $1000 \mathrm{~m}$ 河段缓冲区 & 88.67 & 4.78 & 95.96 & 2.5 & 0.130 & Farmland (34.2)、SHDI(24.1) \\
\hline & $500 \mathrm{~m}$ 河岸带缓冲区 & 83.74 & 4.03 & 90.13 & 2.4 & 0.086 & Forest (32.1)、Water(23.1) \\
\hline & 子流域 & 85.32 & 4.88 & 91.72 & 0.8 & 0.474 & Unused( 10.9)、Grass (9.3) \\
\hline \multirow[t]{3}{*}{ 秋季 } & $1000 \mathrm{~m}$ 河段缓冲区 & 78.67 & 9.30 & 90.51 & 2.1 & 0.126 & Farmland (30.6) 、SHDI( 25.4) \\
\hline & $500 \mathrm{~m}$ 河岸带缓冲区 & 61.39 & 12.44 & 76.09 & 2.3 & 0.116 & Forest (27.4)、Farmland (19.4) \\
\hline & 子流域 & 73.48 & 12.52 & 86.61 & 0.8 & 0.446 & Farmland (11.5)、Water (10.6) \\
\hline \multirow[t]{3}{*}{ 冬季 } & $1000 \mathrm{~m}$ 河段缓冲区 & 88.72 & 3.78 & 93.27 & 3.5 & 0.054 & Farmland(39.1)、SHDI(25.0) \\
\hline & $500 \mathrm{~m}$ 河岸带缓冲区 & 82.39 & 3.87 & 89.00 & 4.5 & 0.038 & Forest $(44.1) 、 P D(10.9)$ \\
\hline & 子流域 & 78.51 & 3.88 & 84.58 & 0.7 & 0.434 & Unused(10.0)、SHDI(9.5) \\
\hline
\end{tabular}

* 解释变量包括 Grass-草地、Water-水域、Farmland-耕地、Urban-建设用地、Forest-林地、Unused-未利用土地、PD-斑块密度 和 SHDI-香农多样性指数.

\section{3 讨论}

\section{1 土地利用对水质的多时空尺度影响}

本研究对于土地利用指数的选取包括土地利用类型百分比和景观空间结构两个方面, 在不同的时空尺 度下, 不同土地利用指数对水质的影响存在明显差异, 与前人研究结论相符 ${ }^{[2,4,16]}$. 在多数时空尺度下, 耕地 面积占比与 $\mathrm{NH}_{3}-\mathrm{N}$ 和 $\mathrm{COD}_{\mathrm{Mn}}$ 浓度呈现较大的正相关性(图 4), 体现了 “源” 景观对水质的负面作用 ${ }^{[32]}$. 在人 为作用的干扰下, 耕地景观破碎程度大, 加上大量使用化肥农药的影响, 污染物浓度不断增加, 经地表径流 等方式集中到河流中, 导致水质恶化. 相较于 $1000 \mathrm{~m}$ 河段缓冲区和 $500 \mathrm{~m}$ 河岸带缓冲区尺度, 子流域尺度上 土地利用与水质的相关性较弱. 这是因为耕地面积占比在该空间尺度上相对最小, 并且随着流域面积的增 加, 污染物迁移时间越长, 降解量也就越大, 对水质的恶化作用也会相应降低 ${ }^{[12]}$. 在各时空尺度下, $P D$ 指数 均与 $\mathrm{NH}_{3}-\mathrm{N}$ 和 $\mathrm{COD}_{\mathrm{Mn}}$ 浓度呈正相关, 并且在 $1000 \mathrm{~m}$ 河段缓冲区和 $500 \mathrm{~m}$ 河岸带缓冲区尺度下, $P D$ 与水质 指标的相关性强于子流域尺度 (图 4). 这是因为 $P D$ 值的大小可表征景观斑块的破碎程度, $P D$ 值越大, 越容 易造成严重的土壤侵蚀 ${ }^{[11]}$. 

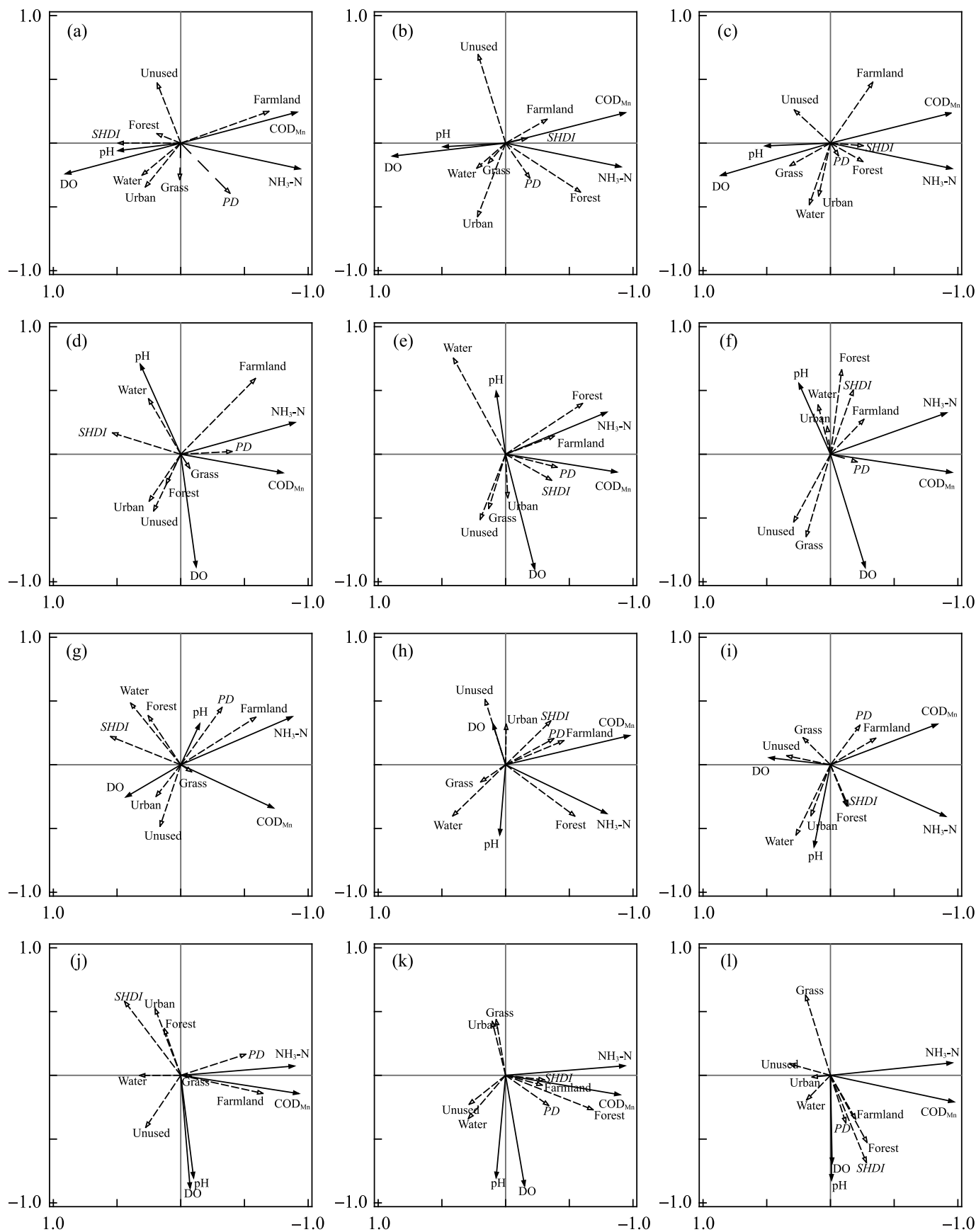

图 4 黄河流域元余分析结果排序图

(环境变量为虚线空心箭头, 包括 Grass-草地, Water-水域,Farmland-耕地, Urban-建设用地, Forest-林地, Unused-未利用土地, $P D$-斑块密度, $S H D I$-香农多样性指数; 物种变量为实线实心箭头, 水质指数包括 $\mathrm{pH}$, $\mathrm{DO}$-溶解氧, $\mathrm{NH}_{3}-\mathrm{N}$-氨氮和 $\mathrm{COD}_{\mathrm{Mn}}$-高锰酸盐指数; ( a )、(b)、(c) 为春季河段、河岸带和子流域 尺度的 RDA 结果, (d)、(e)、(f) 为夏季河段、河岸带和子流域尺度的 RDA 结果, (g)、(h)、(i) 为秋季河段、 河岸带和子流域尺度的 RDA 结果, $(\mathrm{j}) 、(\mathrm{k}) 、(1)$ 为冬季河段、河岸带和子流域尺度的 RDA 结果)

Fig.4 Ordination diagrams originated of redundancy analysis (RDA) results in the Yellow River Basin 
草地在大多数时空尺度下与 $\mathrm{NH}_{3}-\mathrm{N}$ 和 $\mathrm{COD}_{\mathrm{Mn}}$ 浓度呈负相关, 与 $\mathrm{pH}$ 和 $\mathrm{DO}$ 浓度呈正相关, 对水质有净化 作用 (图 4), 与前人研究结论一致 ${ }^{[2,32]}$. 林地在 $1000 \mathrm{~m}$ 河段缓冲区尺度下,与 $\mathrm{NH}_{3}-\mathrm{N}$ 和 $\mathrm{COD}_{\mathrm{Mn}}$ 的关系为负相 关,与而在 $500 \mathrm{~m}$ 河岸带缓冲区和子流域尺度表现为正相关 (图 4). 以往研究表明,作为典型的 “汇” 景观, 林地对水化学元素具有吸收、截留的作用, 从而能够保持水土、净化水质 ${ }^{[11]}$. 但河段缓冲区尺度下, 景观破 碎程度相对较大, 对污染物的吸收降解作用有所降低; 且城市绿化用地距离河流较近, 在种植过程中使用的 化肥农药排人河流, 导致水质降低 ${ }^{[33]}$. 水域面积在降雨、地表径流的综合作用下, 与水质呈现负相关, 对水 质污染有稀释作用 ${ }^{[6]}$. 未利用土地由于人类活动的干扰较少, 表现出与耕地相反的相关性, 对河流排放污染 少, 对水质安全表现出有利的一面. SHDI 指数在一些研究中被认为对水质存在负面作用 ${ }^{[6,20]}$, 但在本研究中 表现为对水质的正面作用. 产生这种差异的原因可能是研究区域内主要景观类型不同,这些研究区域以林 地和草地景观为主, 而黄河流域内耕地占据了主导地位. 因此, SHDI 值越大, 景观多样性越丰富, 导致林地、 草地等景观的净化作用增强, 而对黄河流域内的水质保护有积极作用, 能够有效防止污染物扩散. 之前有研 究表明随着建设用地增加, 道路、房屋等城镇不透水面上的污染物会随着雨水冲刷到河流, 从而造成水质恶

化 ${ }^{[10,16,20]}$. 而本研究结果显示建设用地在多数时空尺度下与 $\mathrm{NH}_{3}-\mathrm{N}$ 和 $\mathrm{COD}_{\mathrm{Mn}}$ 浓度呈负相关 (图 4), 表明建 筑用地面积的增加并未对流域水质产生负面的影响, 原因可能是研究区内多数监测点附近的建筑用地面积 较少, 城镇规模较小, 建筑用地面积比不足以作为影响水质的关键因子, 这与王杰等的研究结果一致 ${ }^{[4]}$.

\section{2 土地利用对水质影响的时空尺度效应}

河流水质的变化与植被覆盖和地表径流量息息相关. 研究结果显示, 在夏季和 $1000 \mathrm{~m}$ 河段缓冲区尺度 下, 呪余分析得到的解释率最高, 土地利用与水质的相关关系最为显著. 黄河流域以玉米、小麦等经济作物 为主, 主要分布在内蒙古、宁夏、陕西、甘肃、山西、青海、山东、河南等地, 全面覆盖了本研究所在区域, 春玉 米和春小麦主要分布在黄河流域中上游, 夏玉米主要分布在黄河流域中下游 ${ }^{[34]}$, 其生长期主要为 5-9 月, 这一阶段农户对耕地进行大量施肥工作, 污染物浓度急剧增加. 并且夏季降雨集中,降水量达到一年中的峰 值, 污染源通过地表径流的方式排人河流, 导致夏季在各空间尺度下解释率均较大, 与欧洋等 ${ }^{[35}$ 得到的雨季 时景观对水质解释能力最强这一结论相符. 蔡宏等 ${ }^{[22]}$ 的研究表明, 相较于缓冲区尺度, 子流域尺度水质对 景观指数的响应更为显著. 而方娜等 ${ }^{[14]}$ 对鄱阳湖的研究发现, 缓冲区尺度土地利用对水质的解释率高于子 流域尺度, 与本研究 $1000 \mathrm{~m}$ 河段缓冲区解释率最高一致, 距离监测点越近, 土地利用对水质影响越大. 产生 这种差异的主要原因是在不同地区, 由于土地利用空间分布的不同,水文迁移的过程存在差异. 因此,对于 黄河流域,夏季和河段缓冲区尺度更能体现土地利用对水质参数的响应.

\section{4 结论}

1) 在夏季和 $1000 \mathrm{~m}$ 河段缓冲区尺度上, 土地利用指数对水质指标的解释率最大, 对黄河流域保护水资 源最具有指导意义. 在夏季降雨量增多时, 应有效控制农田中化肥农药的使用量, 避免污染物在近河岸处的 直接排放.

2) 在不同的时空尺度下, 不同土地利用指数对水质的影响差异明显, 对水质影响最显著的土地利用指 数为林地、草地和 $P D$ 指数. 草地、水域、未利用土地面积占比及 $S H D I$ 的增加对水质具有正面效应, 能够有效 保护水质安全; 而耕地和建设用地、 $P D$ 值的增加则会加剧水化学污染, 导致流域水质恶化. 对于林地景观, 需要发挥其在 $1000 \mathrm{~m}$ 河段缓冲区尺度上的积极影响,通过土地利用的合理规划, 增强其在河岸带和子流域 尺度上的水质净化作用. 通过植树造林、退耕还林等措施提高植被覆盖率, 保护现有水域水质; 在进行城市 土地规划时,降低各土地利用的破碎程度,减少黄河流域土壤侵蚀带来的负面影响.

3) 通过对黄河流域不同时空尺度下土地利用指数与水质的定量关系展开研究, 确定了对水质管理最有 效的时空尺度,并反映了不同土地利用指数对水质影响的相关性. 根据研究结果可有效采取措施对黄河流 域水质进行管理和优化, 对保护水生态环境具有参考价值. 但本研究仍存在一些不足, 由于 Landsat 遥感数 据分辨率较低,可能对监督分类精度造成影响,在后续研究中,可采用更高分辨率影像进行解译.

\section{5 参考文献}

[ 1 ] Yang ST, Yu XY, Ding JL et al. A review of water issues research in Central Asia. Acta Geographica Sinica, 2017, 72 
(1) : 79-93. DOI: 10.11821/dlxb201701007. [杨胜天, 于心怡, 丁建丽等. 中亚地区水问题研究综述. 地理学报, 2017, 72(1): 79-93.]

[ 2 ] Lv ZQ, Qing XY, Ren YF et al. Effects of land use pattern on water quality in mountainous City-A case study of Chongqing City. J Lake Sci, 2016, 28(2) : 319-327. DOI: 10.18307/2016.0211. [吕志强, 庆旭瑶, 任玉芬等. 山地 城市河流土地利用结构对水质的影响一以重庆市为例. 湖泊科学, 2016, 28(2): 319-327.]

[ 3 ] Liu YN, Kong LQ, Xiao Y et al. Relationships between landscape pattern and ecosystem water purification service in the Yangtze River Basin. Acta Ecologica Sinica, 2019, 39(3) : 844-852. DOI: 10.5846/stxb201801130100. [刘怡娜, 孔令 桥, 肖淡等. 长江流域景观格局与生态系统水质净化服务的关系. 生态学报, 2019, 39(3) : 844-852.]

[ 4 ] Wang J, Li P, Gao HD et al. Preliminary study on the relationship between land use/landscape index and water quality in the upper reaches of Danjiang river. Research of Soil and Water Conservation, 2018, 25(6) : 383-389. [王杰, 李鹏, 高 海东等. 丹江上游土地利用/景观指数与水质关系初探. 水土保持研究, 2018, 25(6) : 383-389.]

[ 5 ] Liu JH, Yu Q, Yang D et al. Spatial heterogeneity of groundwater and its response to landscape pattern evolution in Dengkou County. Transactions of the Chinese Society for Agricultural Machinery, 2019, 50(12): 205-212. [刘建华, 于强, YANG Di 等. 磴口县地下水空间异质性分析及其对景观格局变化的响应. 农业机械学报, 2019, 50(12): 205-212.]

[6] Ji DQ, Wen Y, Wei JB et al. Relationships between landscape spatial characteristics and surface water quality in the Liu Xi River watershed. Acta Ecologica Sinica, 2015, 35(2) : 246-253. DOI: 10.5846/stxb201303230496. [吉冬青, 文雅, 魏建兵等. 流溪河流域景观空间特征与河流水质的关联分析. 生态学报, 2015, 35(2): 246-253.]

[ 7 ] Tong STY, Chen WL. Modeling the relationship between land use and surface water quality. Journal of Environmental Management, 2002, 66(4) : 377-393. DOI: 10.1006/jema.2002.0593.

[ 8 ] Meneses BM, Reis R, Vale MJ et al. Land use and land cover changes in Zêzere watershed (Portugal) -Water quality implications. Science of the Total Environment, 2015, 527/528: 439-447. DOI: 10.1016/j. scitotenv.2015.04.092.

[ 9 ] Yang J, Xu YP, Gao B et al. River water quality change and its relationship with landscape pattern under the urbanization: A case study of Suzhou City in Taihu Basin. J Lake Sci, 2017, 29(4) : 827-835. DOI: 10.18307/2017.0406. [杨 洁, 许有鹏, 高斌等. 城镇化下河流水质变化及其与景观格局关系分析一以太湖流域苏州市为例. 湖泊科学, $2017,29(4): 827-835$. ]

[10] Shi P, Zhang Y, Li ZB et al. Influence of land use and land cover patterns on seasonal water quality at multi-spatial scales. CATENA, 2017, 151: 182-190. DOI: 10.1016/j.catena.2016.12.017.

[11] Zhou JJ, Xiang J, Wang LY et al. Relationship between landscape pattern and hydrochemical characteristics of Binggou River Basin in eastern Qilian Mountains. Chinese Journal of Ecology, 2019, 38(12) : 3779-3788. DOI: 10.13292/j.10004890.201912.032. [周俊菊, 向鹃, 王兰英等. 祁连山东部冰沟河流域景观格局与河流水化学特征关系. 生态学杂 志, 2019, 38(12) : 3779-3788.]

[12] Zhang YJ, Chen S, Xiang JC. Correlation between the water quality and land use composition in the river side area-a case of Chaohu Lake Basin in China. Resources and Environment in the Yangtze Basin, 2011, 20(9) : 1054-1061. [张殷 俊, 陈爽, 相景昌. 河流近域土地利用格局与水质相关性分析一一以巢湖流域为例. 长江流域资源与环境, 2011, 20(9) : 1054-1061.]

[13] Wang YK, Cheng RH, Zeng P et al. Spatial differentiation of water quality in river networks in Shanghai and its response to land use in riparian zones. Journal of Ecology and Rural Environment, 2019, 35(7) : 925-932. [汪昱昆, 程锐辉, 曾 鹏等.上海地区河网水质空间分异及对河岸带土地利用的响应. 生态与农村环境学报, 2019, 35(7): 925-932.]

[14] Fang N, Liu LL, You QH et al. Effects of land use types at different spatial scales on water quality in Poyang lake wetland. Environmental Science, 2019, 40(12) : 5348-5357. DOI: 10.13227/j.hjkx.201903267. [方娜, 刘玲玲, 游清徽等. 不 同尺度土地利用方式对鄱阳湖湿地水质的影响. 环境科学, 2019, 40(12) : 5348-5357.]

[15] de Mello K, Valente RA, Randhir TO et al. Effects of land use and land cover on water quality of low-order streams in Southeastern Brazil: Watershed versus riparian zone. CATENA, 2018, 167: 130-138. DOI: 10. 1016/j. catena. 2018. 04.027.

[16] Zhang J, Li SY, Dong RZ et al. Influences of land use metrics at multi-spatial scales on seasonal water quality: A case study of river systems in the Three Gorges Reservoir Area, China. Journal of Cleaner Production, 2019, 206: 76-85. DOI: 10.1016/j.jclepro.2018.09.179. 
[17] Wang J, Zhang F, Zhang Y et al. Correlation between the spatial water quality and land use/cover in the Ebinur Lake area. Acta Ecologica Sinica , 2016, 36(24) : 7971-7980. DOI: 10.5846/stxb201505271059. [王娟, 张飞, 张月等. 艾比 湖区域水质空间分布特征及其与土地利用/覆被类型的关系. 生态学报, 2016, 36(24): 7971-7980.]

[18] Yang HC, Wang GQ, Wang LJ et al. Impact of land use changes on water quality in headwaters of the Three Gorges Reservoir. Environmental Science and Pollution Research, 2016, 23(12) : 11448-11460. DOI: 10.1007/s11356-015-5922-4.

[19] Tu J, Xia ZG. Examining spatially varying relationships between land use and water quality using geographically weighted regression I: Model design and evaluation. Science of the Total Environment, 2008, 407(1) : 358-378. DOI: 10.1016/j. scitotenv.2008.09.031.

[20] Ding J, Jiang Y, Liu Q et al. Influences of the land use pattern on water quality in low-order streams of the Dongjiang River basin, China: A multi-scale analysis. Science of the Total Environment, 2016, 551/552 : 205-216. DOI: 10.1016/j.scitotenv.2016.01.162.

[21] Kang WH, Cai H, Lin GM et al. Influences of landscape on river quality under different geomorphological conditions. Acta Ecologica Sinica, 2020, 40(3) : 1031-1043. DOI: 10.5846/stxb201811182498. [康文华, 蔡宏, 林国敏等. 不同地貌 条件下景观对河流水质的影响差异. 生态学报, 2020, 40(3) : 1031-1043.]

[22] Cai H, He ZW, An YL et al. Response relationship between land use and water quality in Chishui river basin based on rs and GIS. Resources and Environment in the Yangtze Basin, 2015, 24(2) : 286-291. DOI: 10.11870/cjlyzyyhj201502015. [蔡宏, 何政伟, 安艳玲等. 基于遥感和 GIS 的赤水河水质对流域土地利用的响应研究. 长江流域资源与环境, $2015, \mathbf{2 4}(2): 286-291$.]

[23] Lu DD, Sun DQ. Development and management tasks of the Yellow River Basin: A preliminary understanding and suggestion. Acta Geographica Sinica, 2019, 74(12) : 2431-2436. DOI: 10.11821/dlxb201912001. [陆大道, 孙东琪. 黄河流 域的综合治理与可持续发展. 地理学报, 2019, 74(12): 2431-2436.]

[24] Yu XJ, Xue ZS, Zhang ZS et al. Impacts of tidal channels on typical landscapes of wetland in the Yellow River Delta. Journal of Natural Resources, 2019, 34(12) : 2504-2515. [于小娟, 薛振山, 张仲胜等. 潮沟对黄河三角洲湿地典型 景观格局的影响. 自然资源学报, 2019, 34(12) : 2504-2515.]

[25] Zhang DW, Li YF, Sun X et al. Relationship between landscape pattern and river water quality in Wujingang region, Taihu lake watershed. Environmental Science, 2010, 31(8) : 1775-1783. DOI: 10.13227/j.hjkx.2010.08.026. [张大伟, 李杨帆, 孙翔等. 人太湖河流武进港的区域景观格局与河流水质相关性分析. 环境科学, 2010, 31 (8): 1775-1783.]

[26] Zhang J, Li SY, Jiang CS. Effects of land use on water quality in a River Basin (Daning) of the Three Gorges Reservoir Area, China: Watershed versus riparian zone. Ecological Indicators, 2020, 113: 106226. DOI: 10. 1016/j. ecolind. 2020.106226.

[27] Liu LY, Ding SY, Ren JY et al. Effects of landscape spatial heterogeneity on surface water quality service: A case study in Yihe River basin, Henan Province. Geographical Research, 2019, 38(6) : 1527-1541. DOI: 10.11821/dlyj020180235. [刘绿怡, 丁圣彦, 任嘉衍等. 景观空间异质性对地表水质服务的影响研究一一河南省伊河流域为例. 地理研 究, 2019, 38(6) : 1527-1541.]

[28] Lv ZY, Mu JX. Study on spatial and temporal evolution feature of water quality in Yellow River Basin. Yellow River, 2017, 39(4): 66-70, 77. [吕振豫, 穆建新. 黄河流域水质污染时空演变特征研究. 人民黄河, 2017, 39(4): 66$70,77$.

[29] Zheng ZY, Lv MX, Ma ZG. Climate, hydrology, and vegetation coverage changes in source region of Yellow River and countermeasures for challenges. Bulletin of Chinese Academy of Sciences, 2020, 35(1)：61-72. [郑子彦, 吕美霞, 马柱 国. 黄河源区气候水文和植被覆盖变化及面临问题的对策建议. 中国科学院院刊, 2020, 35(1): 61-72.]

[30] Zhao LL, Liu ZY, Wang JX. Analysis of extreme hydrological events characteristics of Yellow River Basin under climate change. Journal of China Hydrology, 2015, 35(5): 78-81, 90. [赵兰兰, 刘志雨, 王金星. 气候变化下的黄河流域极 端水文现象特征分析. 水文, $2015, \mathbf{3 5}(5): 78-81,90$.

[31] Ma ZG, Fu CB, Zhou TJ et al. Status and ponder of climate and hydrology changes in the Yellow River Basin. Bulletin of Chinese Academy of Sciences, 2020, 35(1) : 52-60. [马柱国, 符淙斌, 周天军等. 黄河流域气候与水文变化的现状 及思考. 中国科学院院刊, 2020, 35(1): 52-60.]

[32] Zhang YJ, Li CW, Hu BB et al. Impact of a “source-sink” landscape pattern in an urbanized watershed on nitrogen and 
phosphorus spatial variations in rivers: A case study of Yuqiao Reservoir watershed, Tianjin, China. Acta Ecologica Sini$c a, 2017,37(7)$ : 2437-2446. DOI: 10.5846/stxb201512242566. [张亚娟, 李崇巍, 胡蓓蓓等. 城镇化流域“源-汇” 景观格局对河流氮磷空间分异的影响——天津于桥水库流域为例. 生态学报, 2017, 37(7): 2437-2446. ]

[33] Li K, Wang L, Sun W et al. Spatial effect of landscape pattern on river water quality under urbanization. Acta Scientiae Circumstantiae, 2020, 40 (1) : 343-352. DOI: 10.13671/j.hjkxxb.2019.0330. [李昆, 王玲, 孙伟等. 城市化下景观格 局对河流水质变化的空间尺度效应分析. 环境科学学报, 2020, 40(1) : 343-352.]

[34] Shao XM, Yan CR. Study on the pattern of water requirements of main crops and rainfall in the Yellow River Basin. Chinese Journal of Agrometeorology, 2007, 28(1): 40-44. [邵晓梅, 严昌荣. 黄河流域主要农作物的降水盈亏格局分析. 中国农业气象, 2007, 28(1): 40-44.]

[35] Ou Y, Wang XY, Geng RZ. The influences of different landscape characteristics on water quality in the upper watershed of Miyun Reservoir. Acta Scientiae Circumstantiae, 2012, 32(5): 1219-1226. [欧洋, 王晓燕, 耿润哲. 密云水库上游流 域不同尺度景观特征对水质的影响. 环境科学学报, 2012, 32(5): 1219-1226.] 